University of Montana

ScholarWorks at University of Montana

$11-2004$

\title{
The Effects of Postfire Salvage Logging on Aquatic Ecosystems in the American West
}

J. R. Karr

JJ Rhodes

GW Minshall

F. Richard Hauer

University of Montana - Missoula, ric.hauer@umontana.edu

R. L. Beschta

See next page for additional authors

Follow this and additional works at: https://scholarworks.umt.edu/biosci_pubs

Part of the Biology Commons

Let us know how access to this document benefits you.

\section{Recommended Citation}

Karr, J. R.; Rhodes, JJ; Minshall, GW; Hauer, F. Richard; Beschta, R. L.; Frissell, C. A.; and Perry, D. A., "The Effects of Postfire Salvage Logging on Aquatic Ecosystems in the American West" (2004). Biological Sciences Faculty Publications. 54.

https://scholarworks.umt.edu/biosci_pubs/54

This Article is brought to you for free and open access by the Biological Sciences at ScholarWorks at University of Montana. It has been accepted for inclusion in Biological Sciences Faculty Publications by an authorized administrator of ScholarWorks at University of Montana. For more information, please contact scholarworks@mso.umt.edu. 


\section{Authors}

J. R. Karr, JJ Rhodes, GW Minshall, F. Richard Hauer, R. L. Beschta, C. A. Frissell, and D. A. Perry 


\title{
The Effects of Postfire Salvage Logging on Aquatic Ecosystems in the American West
}

\author{
JAMES R. KARR, JONATHAN J. RHODES, G. WAYNE MINSHALL, F. RICHARD HAUER, \\ ROBERT L. BESCHTA, CHRISTOPHER A. FRISSELL, AND DAVID A. PERRY
}

Recent changes in the forest policies, regulations, and laws affecting public lands encourage postfire salvage logging, an activity that all too often delays or prevents recovery. In contrast, the 10 recommendations proposed here can improve the condition of watersheds and aquatic ecosystems.

Keywords: aquatic ecosystems, postfire salvage logging, public land management, salmonids, western forests

$\mathbf{T}$ hroughout the American West, a century of road building, logging, grazing, and other human activities has degraded stream environments, causing significant losses of aquatic biodiversity and severe contractions in the range and abundance of sensitive aquatic species, including native salmonid fishes (Rieman et al. 2003). Compounding these problems, federal land management has worsened ecological degradation, rather than conserving or restoring forest ecosystems (Leopold 1937, Langston 1995, Hirt 1996). Land managers' focus on commodity extraction - sharpened by recent changes in forest policy, regulations, and laws that encourage salvage logging after fires- perpetuates this trend and its harmful impacts. Here we focus on the effects of such postfire salvage logging on public lands and aquatic ecosystems. To curb ecological damage from postfire salvage logging, we urge the adoption of 10 recommendations based on decades of ecological research.

Although often done in the name of postfire restoration, salvage logging typically delays or prevents natural recovery in several important ways (Beschta et al. 1995, 2004, Lindenmayer et al. 2004). These impacts tend to have a multiplier effect, because fire-affected ecosystems are sensitive to further disturbances.

- Postfire salvage logging generally damages soils by compacting them, by removing vital organic material, and by increasing the amount and duration of topsoil erosion and runoff (Kattleman 1996), which in turn harms aquatic ecosystems. The potential for damage to soil and water resources is especially severe when ground-based machinery is used.

- Postfire salvage logging has numerous ecological ramifications. The removal of burned trees that provide shade may hamper tree regeneration, especially on high-elevation or dry sites (Perry et al. 1989). The loss of future soil organic matter is likely to translate into soils that are less able to hold moisture (Jenny 1980), with implications for soil biota, plant growth (Rose et al. 2001, Brown et al. 2003), and stream flow (Waring and Schlesinger 1985). Logging and associated roads carry a high risk of spreading nonindigenous, weedy species (CWWR 1996, Beschta et al. 2004).

- Increased runoff and erosion alter river hydrology by increasing the frequency and magnitude of erosive high flows and raising sediment loads. These changes alter the character of river channels and harm aquatic species ranging from invertebrates to fishes (Waters 1995).

- Construction and reconstruction of roads and landings (sites to which trees are brought, stacked, and loaded onto trucks) often accompany postfire salvage logging. These activities damage soils, destroy or alter vegetation, and accelerate the runoff and erosion harmful to aquatic systems (figure 1).

- By altering the character and condition of forest vegetation, salvage logging after a fire changes forest fuels and can increase the severity of subsequent fires (CWWR 1996, Odion et al. 2004).

James R. Karr (e-mail: jrkarr@u.washington.edu) is a professor in the School of Aquatic and Fishery Sciences and the Department of Biology, University of Washington, Seattle, WA 98195. Jonathan J. Rhodes is a senior hydrologist at Planeto Azul Hydrologic Consultants, Portland, OR 97293. G. Wayne Minshall is a professor emeritus in the Department of Biological Sciences, Idaho State University, Pocatello, ID 83209. F. Richard Hauer is a professor at the Flathead Lake Biological Station, Division of Biological Sciences, University of Montana, Polson, MT 59860. Robert L. Beschta is a professor emeritus in the Department of Forest Engineering, and David A. Perry is a professor emeritus in the Department of Forest Science, at Oregon State University, Corvallis, OR 97331 (Perry's current address is PO Box 8, Kapa'au, HI 96755). Christopher A. Frissell is a watershed ecologist and fishery biologist at the Pacific Rivers Council, Polson, MT 59860. ๑ 2004 American Institute of Biological Sciences. 

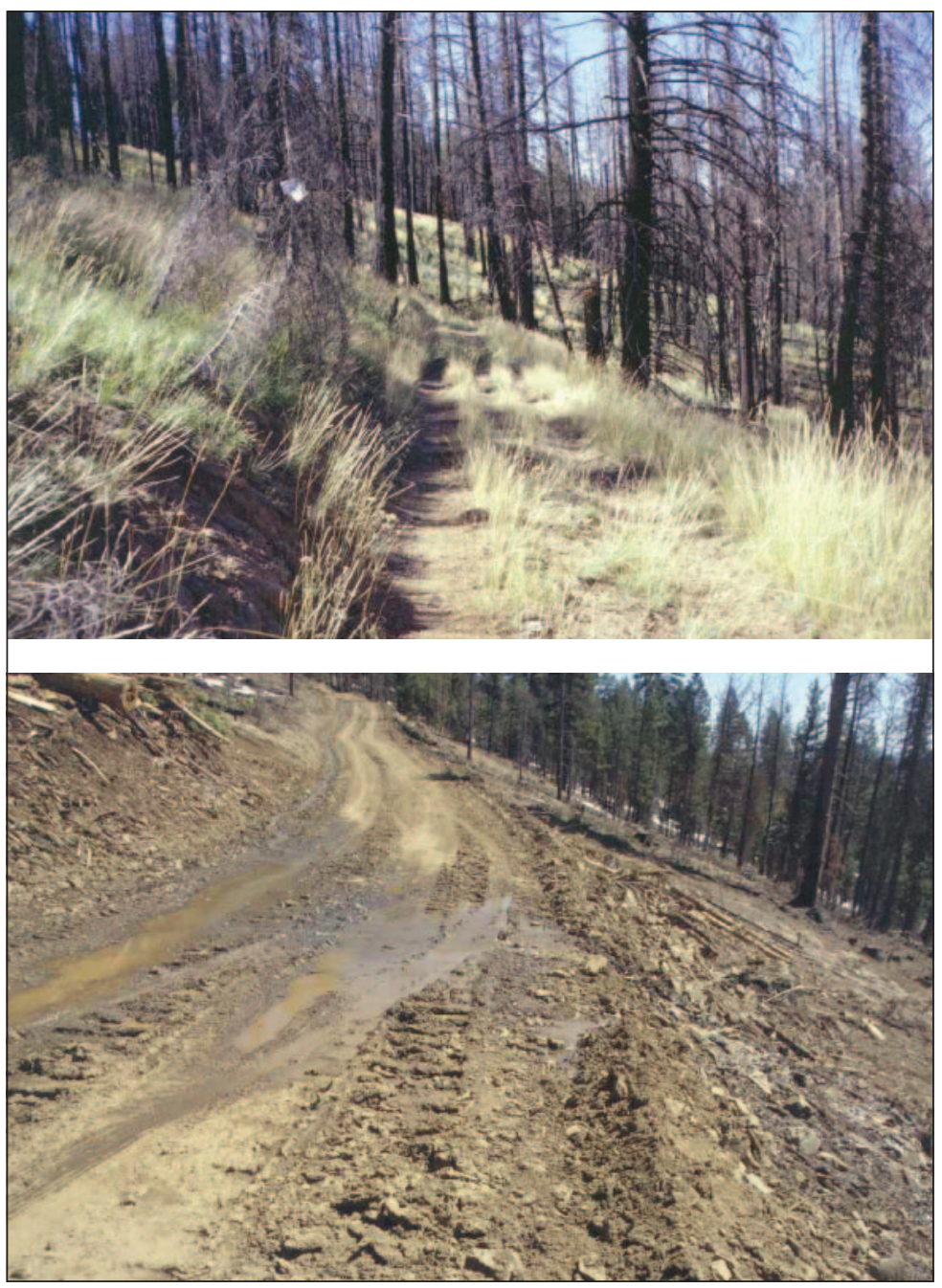

Figure 1. Postfire recovery and salvage logging in the Malheur National Forest, Oregon. After a 1996 fire, vegetation along an old road was recovering naturally in 1998 (top). In 1999, road reconstruction and salvage logging on the same slopes (bottom) reversed this recovery, increasing soil erosion and surface runoff into a tributary that supports steelhead trout (Oncorhynchus mykiss), a salmonid listed as threatened at the time under the Endangered Species Act. Such increases in sediment delivery lower the survival rates of steelhead and other aquatic species. Photographs: Jonathan J. Rhodes.

- Postfire salvage logging undermines the effectiveness of other costly postfire rehabilitation efforts, most of which are aimed at reducing soil erosion and runoff (Robichaud et al. 2000).

In short, by adding another stressor to burned watersheds, postfire salvage logging worsens degraded aquatic conditions accumulated from a century of human activity (CWWR 1996, NRC 1996, 2002, McIntosh et al. 2000). The additional damage impedes the recovery and restoration of aquatic systems, lowers water quality, shrinks the distribution and abundance of native aquatic species, and compromises the flow of economic benefits to human communities that depend on aquatic resources (Beschta et al. 2004).

The impacts of fire, and of salvage logging and its associated activities, vary in severity from site to site, depending on a site's natural conditions and on its history of human use. Fires burn in a mosaic of intensities; most areas burn at moderate to low intensity. High-severity burns place the most stress on watersheds and aquatic systems. By themselves, the effects of fire create few problems for aquatic populations that have access to high-quality stream environments (Gresswell 1999); fire even provides benefits, such as pulsed additions of spawning gravel and wood. But where a history of environmental degradation and fragmentation of aquatic populations already exists, fire can threaten certain species, and salvage logging adds another layer of stress.

The effects of postfire salvage logging are especially significant on steep slopes, in erosion-prone soils, on severely burned sites (where the impacts listed above can be particularly pronounced), and in riparian and roadless areas. Riparian areas affect aquatic environments more than remoter uplands do; they influence water quality, physical habitat, and the abundance of aquatic species (Gregory et al. 1991, Naiman et al. 1998). Logging, landings, and roads in riparian zones degrade aquatic environments by lessening the amount of large wood in streams, elevating water temperature, altering near-stream hydrology, and increasing sedimentation. Roadless areas comprise some of the least disturbed living systems and are therefore especially important to the restoration of watersheds and freshwater systems. Consequently, logging activities in these areas undermine the conservation and restoration of aquatic ecosystems (FEMAT 1993, Henjum et al. 1994) even as they increase the risk of extirpation for already imperiled, fragmented, and sensitive populations.

\section{Avoiding damage from salvage logging: Ten recommendations}

Continued postfire salvage logging ignores many threats to aquatic resources, virtually guaranteeing trajectories toward unsustainable ecosystems. Halting this deterioration should be a policy priority. To protect streams, wetlands, and associated watersheds and to foster their restoration, we offer the following 10 policy recommendations.

\section{Allow natural recovery to occur on its own, or intervene only in ways that promote natural recovery. Many interventions in postfire landscapes delay or prevent recovery by adding to fires' short-term effects. Allowing unimpeded natural recov- ery of burned landscapes is typically more cost-effective and often results in more rapid recovery than postfire salvage logging (Kauffman et al. 1997). Natural recovery is particu- larly important on public lands, which, despite widespread degradation, are still in better condition than many private}


lands. Today public lands represent the best starting point for restoring aquatic systems. In Oregon, for example, 14 of 25 at-risk fish species or subspecies live in watersheds within the boundaries or immediately downstream of national forests (Henjum et al. 1994).

Any intervention should aim to reduce the effects of past and present human disturbances, rather than focus solely on fire impacts: Postfire treatments can and should be compatible with aquatic restoration. A crucial component of aquatic restoration is to maintain and reestablish morenatural process rates (e.g., hydrology, sediment transport, nutrient cycling, and species demographies); obliterating existing roads, for example, would help restore hydrologic and erosion regimes. Recovery is also aided by reestablishing the connectivity of aquatic populations, establishing morenatural flow patterns in regulated or diverted rivers, reducing the extent and consequences of road networks, and diminishing the negative effects of livestock grazing. Lost or damaged parts of ecosystems, such as native species that are imperiled or otherwise important, should be restored along with ecological processes.

Retain old or large trees. Dead or alive, burned or unburned, large trees are vital for postfire recovery; they provide habitat for many species, reduce soil erosion, aid soil formation, and nourish streams as their leaves fall or their trunks decay (Henjum et al. 1994). Whether large dead trees present a fire risk for the future is a matter of debate. Although they typically do not increase fire severity or the rate of fire spread at a fire front when down (Brown et al. 2003), standing dead trees can send flaming debris ahead of a fire front and ignite spot fires. In contrast, there is no debate about the key role that large trees play in aquatic systems and many ecological processes (Rose et al. 2001). Because of the trees' market value, however, postfire logging typically targets large and even live trees.

Protect soils. Fire-affected soils are especially vulnerable to additional disturbance (e.g., compaction or increased erosion). Soils deserve special care because soils and soil productivity are irreplaceable within human time scales and are crucial to forest recovery, stream conditions, and hydrologic processes. Particular care should be taken to protect shallow, severely burned, erosion-prone, and otherwise fragile soils. Although it is best to prevent postfire salvage logging, in some circumstances doing so may not be possible. In such rare circumstances, higher-risk practices, such as logging with ground-based equipment, should not be used, and sensitive areas should be avoided to limit aquatic impacts. No logging should be done on moderately and severely burned areas and on other sites prone to soil damage and excessive sedimentation. Helicopters and full-suspension cable yarding systems that use existing roads and landings damage soils the least, although they may still delay or prevent recovery of vulnerable areas.
Protect ecologically sensitive areas. Riparian and roadless areas, regions with steep slopes, and watersheds with sensitive or imperiled aquatic species should not be salvage logged. Impacts in riparian and roadless areas influence areas with the highest regional biodiversity, including rare and endangered species; they also have wide repercussions that spread across landscapes, including downstream.

\section{Avoid creating new roads and landings in the burned land-}

scape. Roads and landings cause enduring damage to soils and streams, help spread noxious weeds, and hinder revegetation. Roads are a primary cause of reduced water quality and of contractions in the distribution and number of native salmonids on public lands. Reducing road mileage in national forests should be a primary postfire response. A decade ago, for example, the road densities of three national forests in the US Northwest averaged 2.5 miles per square mile (western Colville National Forest; 1 mile $=1.61$ kilometers), 3.5 miles per square mile (Winema National Forest), and 3.7 miles per square mile (Ochoco National Forest) and attained 11.9 miles per square mile in some watersheds (Henjum et al. 1994). On a regional scale, the national forests of California's Sierra Nevada have a mean road density of about 1.7 miles per square mile, despite the relatively high proportion of wilderness and roadless areas within these forests.

Limit reseeding and replanting. Seeding with nonnative species can impede native plant regeneration (Amaranthus et al. 1993, Beyers 2004) and often spreads invasive species in vulnerable fire-affected soils. Native seed sources or colonists are almost always sufficient for early natural reestablishment of native species, so planting should be considered only when natural regeneration is unlikely; such planting should use only regional stocks of native species. When seed sources of particular species have been lost, replanting should supplement those natives that have become reestablished, not overwhelm them. Replanting dense stands of fast-growing conifers-a common postfire management practice-truncates the biologically rich early stages of ecological succession and can increase the severity of future fires (Odion et al. 2004). Other treatments should be carefully scrutinized for their potential to spread noxious weeds. For instance, straw mulch applied extensively to reduce erosion after the 2002 Hayman Fire in Colorado was contaminated with cheatgrass (Robichaud et al. 2003), an invasive grass difficult to control or eradicate once established. Upslope degradation will ultimately influence aquatic ecosystems.

Do not place structures in streams. In-stream structures (e.g., sediment traps, riprap, check dams, or artificially placed large wood) rarely provide ecological benefits that outweigh the physical damage or expense of installing and maintaining them (Beschta et al. 1994). Although events after a fire may appear catastrophic, periodic fire actually provides the pulsed inputs of sediment and wood that are crucial to maintain the complexity of aquatic habitat (Hauer et al. 1999). Sediment 
abatement should focus on reducing or eliminating human sources of sediment (e.g., culverts and roads) because they tend to be chronic. In contrast, protecting and maintaining natural sediment-processing mechanisms should be a priority in burned landscapes.

Protect and restore watersheds before fires occur. Because it is difficult to reverse a fire's effects rapidly after the fact, prefire conservation and restoration are more likely than postfire rehabilitation measures to protect soils, hydrologic patterns, and aquatic resources (Dunham et al. 2003). Actions taken before fires occur-such as removing unnatural migration barriers to reconnect fragmented fish populations and curtailing activities that increase runoff and erosion or degrade water quality and physical habitats — can increase the resiliency of soils, aquatic habitats, fish, and other organisms to the effects of fires. Thus, fire management policies should strive to reestablish the dynamics of 19th-century and earlier fire regimes; natural and prescribed fires may help meet this objective.

Continue research, monitoring, and assessment. Carefully planned research, monitoring, and assessment should be routine components of programs on the effects of postfire forest treatment. Uncertainties about the effects of salvage logging remain; rigorous retrospective evaluation of forest treatments' effects on fire, forests, and aquatic systems are needed before continuing the present practice of aggressive salvage logging. Despite efforts to fund evaluations (i.e., monitoring and assessment) of the effectiveness of thinning and other so-called restoration practices, no such provisions made it into the Healthy Forests Restoration Act of 2003 (Service 2003). Research is needed, for example, to shed light on the long-term responses to fire in low-elevation forests where salvage logging has not taken place and on how aquatic systems are changed by these responses. Improved understanding of these issues should be a priority in the few suitable areas remaining on federal lands. Such areas can serve as experimental controls for research on the effects of fire on wildland watersheds and associated aquatic systems. Longterm, landscape-scale experimental studies should take priority over logging in these areas. Establishing controlslarge, untreated areas in a variety of settings - is vital to longterm environmental research.

Educate the public. Citizen awareness is key to informed management of public lands. Although forest fires are often portrayed as "disasters" or "natural catastrophes," fires are crucial to the maintenance of healthy forests (Gresswell 1999, Pyne 2001) and associated aquatic ecosystems (Beschta et al. 1995, 2004, Lindenmayer et al. 2004). Despite common misconceptions, forest and aquatic ecosystems evolved with, and depend on, natural fire cycles; it is important to recognize this dependence and incorporate it into natural resource decisions. Policymakers and the public need to recognize that not all forests are the same: Some forest types in the western United States are at risk from fires that are abnormally severe and destructive, but in other forest types, severe fires are the norm (Veblen 2003). Throughout much of the West, the climate is sufficiently wet to grow trees, and conditions periodically become dry enough for forests to burn.

\section{Conclusions}

Contrary to these recommendations, changes in regulations, policies, and laws in the past few years seek to expedite postfire salvage logging at the same time that they diminish the role of science in decisionmaking and raise barriers to citizen participation (Service 2003). Many areas burned during the last two years have been partially logged or are proposed for logging. In Arizona, for example, the USDA Forest Service (2004) is proposing to log, using ground-based machinery, more than 40,000 acres (16,196 hectares) that were moderately to severely burned in the 2002 Rodeo-Chediski Fire. The agency's proposal for salvage logging within the area burned by the 2002 Biscuit Fire in Oregon includes more than 8000 acres (3293 hectares) of roadless area in a region noted for its rich biological diversity, including imperiled salmonids. According to Jack Williams, former forest supervisor for the Rogue River and Siskiyou National Forests, the agency's plan risks long-term ecological damage and guarantees controversy that will generate delays, litigation, and protests (Williams 2004). The July 2004 proposal to roll back protection of roadless areas from postfire salvage and other logging may be the single largest rollback of protection of public lands in the nation's history (Pope 2004).

In addition, the Forest Service's requirements for public involvement have been relaxed, making public input into agency decisionmaking more difficult. Some categories of postfire salvage logging are now categorically excluded from requirements for detailed analysis and public disclosure of environmental impacts. The Forest Service is now allowed to use "emergency" exemptions to proceed rapidly with postfire logging on the basis of the burned trees' economic value as timber; ecological losses-economic and noneconomiccan be ignored in seeking such exemptions. These policies and procedures do not, for example, require consideration of watershed protection measures (e.g., retention of large trees, protection of roadless and riparian areas, and protection of local and downstream aquatic resources). They do increase the likelihood of additional harm to aquatic and terrestrial systems, while authorizing the Forest Service to ignore citizen input and scientific information.

Managing public lands for the benefit of present and future generations is a challenge-a process most likely to succeed in an open atmosphere that actively uses existing scientific and technical information and expertise. Our recommendations can serve as core guidelines for averting further harm to aquatic systems already stressed after fires. Success will depend on vision and leadership at the highest levels of government and in land management agencies, as well as on the relevant expertise, authority, and commitment of local public land managers. A commitment to these changes 
at the national and local levels will help to protect the public interest and to conserve our natural heritage in the aquatic environments on and downstream of public lands.

\section{References cited}

Amaranthus MP, Trappe JM, Perry DA. 1993. Soil moisture, native regeneration, and Pinus lambertiana seedling survival, growth, and mycorrhiza formation following wildfire and grass seeding. Restoration Ecology 1: 188-195.

Beschta RL, Platts WS, Kauffman JB, Hill MT. 1994. Artificial stream restoration-money well spent or an expensive failure? Pages 76-104 in Proceedings, Environmental Restoration, Universities Council on Water Resources 1994 Annual Meeting, August 2-5, Big Sky, Montana. Carbondale (IL): Universities Council on Water Resources, Southern Illinois University.

Beschta RL, Frissell CA, Gresswell R, Hauer R, Karr JR, Minshall BW, Perry DA, Rhodes JJ. 1995. Wildfire and Salvage Logging: Recommendations for Ecologically Sound Post-Fire Salvage Logging and Other Post-Fire Treatments on Federal Lands in the West. (21 September 2004; www.saveamericasforests.org/congress/Fire/Beschta-report.htm)

Beschta RL, Rhodes JJ, Kauffman JB, Gresswell RE, Minshall GW, Karr JR, Perry DA, Hauer FR, Frissell CA. 2004. Postfire management on forested public lands of the western United States. Conservation Biology 18: 957-967.

Beyers JL. 2004. Postfire seeding for erosion control: Effectiveness and impacts on native plant communities. Conservation Biology 18: 947-956.

Brown JK, Reinhardt ED, Kramer KA. 2003. Coarse Woody Debris: Managing Benefits and Fire Hazard in the Recovering Forest. Ogden (UT): USDA Forest Service. General Technical Report RMRS-GTR-105.

[CWWR] Centers for Water and Wildland Resources. 1996. Status of the Sierra Nevada: Summary of the Sierra Nevada Ecosystem Project Report. Davis (CA): CWWR, University of California. Wildland Resources Center Report no. 39.

Dunham JB, Young MK, Gresswell RE, Rieman BE. 2003. Effects of fire on fish populations: Landscape perspective on persistence of native fishes and nonnative fish invasions. Forest Ecology and Management 178: 183-196.

[FEMAT] Forest Ecosystem Management Assessment Team. 1993. Forest Ecosystem Management: An Ecological, Economic, and Social Assessment. Portland (OR): USDA Forest Service.

Gregory SV, Swanson FJ, McKee WA, Cummins KW. 1991. An ecosystem perspective of riparian zones. BioScience 41: 540-551.

Gresswell RE. 1999. Fire and aquatic ecosystems in forested biomes of North America. Transactions of the American Fisheries Society 128: 193-221.

Hauer FR, Poole GC, Gangemi JT, Baxter CV. 1999. Large woody debris in bull trout (Salvelinus confluentus) spawning streams of logged and wilderness watersheds in northwest Montana. Canadian Journal of Fisheries and Aquatic Sciences 56: 915-924.

Henjum MG, Karr JR, Bottom DL, Perry DA, Bednarz JC, Wright SG, Beckwitt SA, Beckwitt E. 1994. Interim Protection for Late-Successional Forests, Fisheries, and Watersheds: National Forests East of the Cascade Crest, Oregon and Washington. Bethesda (MD): Wildlife Society. Technical Review 94-2.

Hirt PW. 1996. A Conspiracy of Optimism: Management of the National Forests since World War Two. Lincoln: University of Nebraska Press.

Jenny H. 1980. The Soil Resource: Origin and Behavior. New York: SpringerVerlag.

Kattleman R. 1996. Hydrology and water resources. Pages 855-920 in SNEP Science Team, et al. Sierra Nevada Ecosystem Project Final Report to Congress: Status of the Sierra Nevada, vol. 2. Davis: Centers for Water and Wildland Resources, University of California. Wildland Resources Center Report no 39.
Kauffman JB, Beschta RL, Otting N, Lytjen D. 1997. An ecological perspective of riparian and stream restoration in the western United States. Fisheries 22 (5): 12-24.

Langston N. 1995. Forest Dreams, Forest Nightmares: The Paradox of Old Growth in the Inland West. Seattle: University of Washington Press.

Leopold A. 1937. Conservationist in Mexico. American Forests 43: 118-120, 146.

Lindenmayer DB, Foster DR, Franklin JF, Hunter ML, Noss RF, Schmeigelow FA, Perry D. 2004. Salvage harvesting policies after natural disturbance. Science 303: 1303.

McIntosh BA, Sedell JR, Thurow RF, Clarke SE, Chandler GL. 2000. Historical changes in pool habitats in the Columbia River Basin. Ecological Applications 10: 1478-1496.

Naiman RJ, Fetherston KL, McKay SJ, Chen J. 1998. Riparian forests. Pages 289-323 in Naiman RJ, Bilby RE, eds. River Ecology and Management: Lessons from the Pacific Coastal Ecoregion. New York: Springer.

[NRC] National Research Council. 1996. Upstream: Salmon and Society in the Pacific Northwest. Washington (DC): National Academy Press.

2002. Riparian Areas: Functions and Strategies for Management. Washington (DC): National Academies Press.

Odion DC, Frost E, Strittholt JR, Jiang H, DellaSala DA, Moritz MA. 2004. Patterns of fire severity and forest conditions in the western Klamath Mountains, California. Conservation Biology 18: 927-936.

Perry DA, Amaranthus MP, Borchers JG, Borchers SL, Brainerd RE. 1989. Bootstrapping in ecosystems. BioScience 39: 230-237.

Pope C. 2004. Proposal would drop forestland protections. Seattle Post-Intelligencer. 13 July, pp. A1, A6.

Pyne SJ. 2001. The fires this time, and next. Science 294: 1005-1006.

Rieman BE, Lee D, Burns D, Gresswell R, Young M, Stowell R, Rinne J, Howell P. 2003. Status of native fishes in the western United States and issues for fire and fuels management. Forest Ecology and Management 178: 197-211.

Robichaud PR, Beyers JL, Neary DG. 2000. Evaluating the effectiveness of postfire rehabilitation treatments. Fort Collins (CO): USDA Forest Service. General Technical Report RMRS-GTR-63.

Robichaud P, MacDonald L, Freeouf J, Neary D, Martin D, Ashmun L. 2003. Postfire rehabilitation of the Hayman Fire. Ogden (UT): USDA Forest Service, Rocky Mountain Research Station. General Technical Report RMRS-GTR-114.

Rose CL, Marcot BG, Mellen TK, Ohmann JL, Waddell KL, Lindely DL, Schrieber B. 2001. Decaying wood in Pacific Northwest forests: Concepts and tools for habitat management. Pages 580-623 in Johnson DH, O'Neil TA, eds. Wildlife-Habitat Relationships in Oregon and Washington. Corvallis: Oregon State University Press.

Service RF. 2003. Critics say new law is a bit thin on science. Science 302: 1879. USDA Forest Service. 2004. Record of Decision for the Rodeo-Chediski Fire Salvage Project. Springerville (AZ): USDA Forest Service, ApacheSitgreaves National Forest.

Veblen TT. 2003. Key issues in fire regime research for fuels management and ecological restoration. Pages 259-275 in Omi PN, Joyce LA, tech. eds. 2003. Fire, Fuel Treatments, and Ecological Restoration: Conference Proceedings, April 16-18, 2002; Fort Collins, CO. Fort Collins (CO): USDA Forest Service, Rocky Mountain Research Station. Proceedings RMRS-P-29.

Waring RH, Schlesinger WH. 1985. Forest Ecosystems: Concepts and Management. Orlando (FL): Academic Press.

Waters TF. 1995. Sediment in Streams: Sources, Biological Effects and Control. Bethesda (MD): American Fisheries Society. Monograph 7.

Williams JE. 2004. Biscuit Fire salvage plan doesn't serve public interest. Portland (OR): The Oregonian, 7 July. (21 September 2004; www. oregonlive.com/special/wildfires/index-ssf?/base/editorial/10892020294 6160.xml) 